Provided for non-commercial research and education use. Not for reproduction, distribution or commercial use.

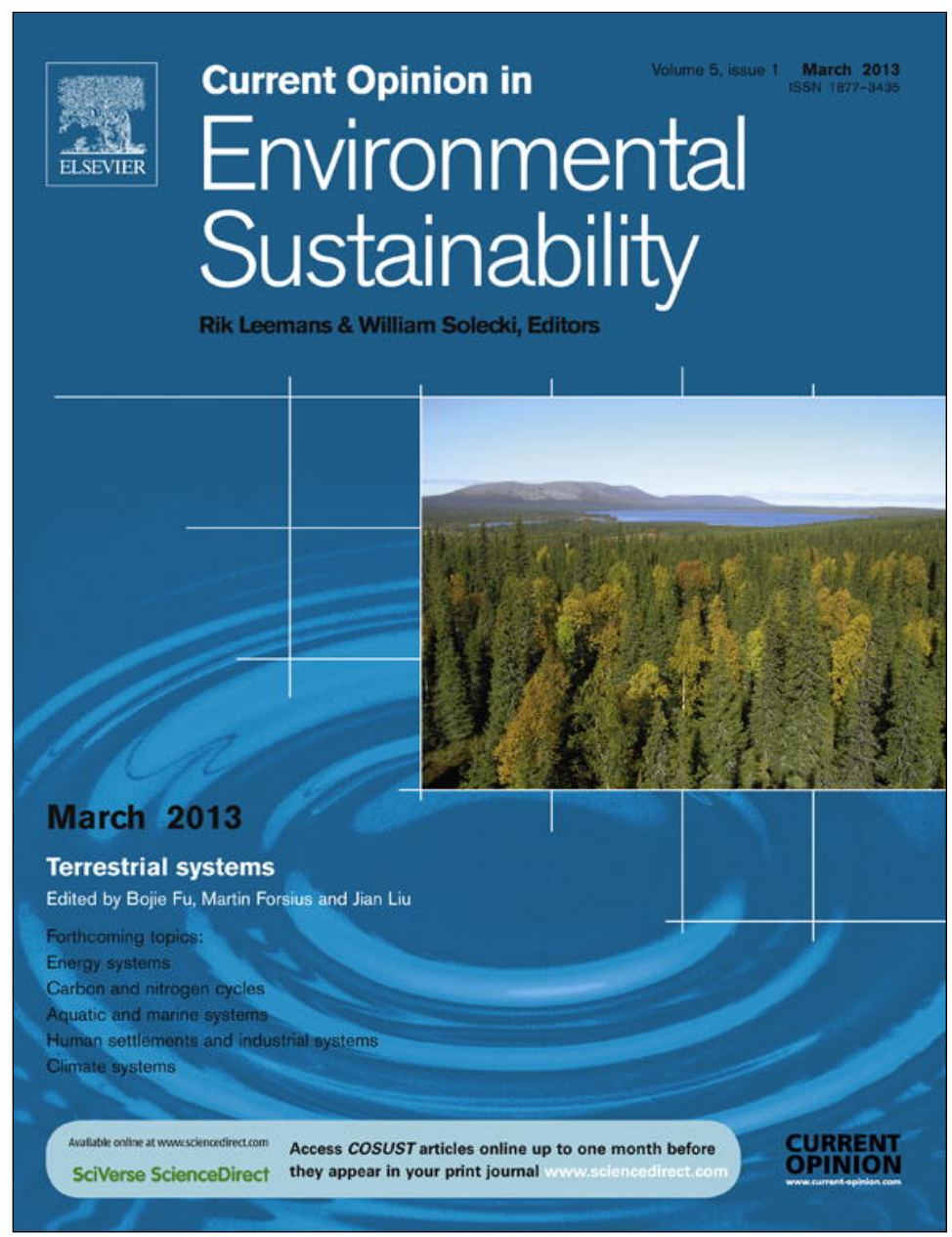

This article appeared in a journal published by Elsevier. The attached copy is furnished to the author for internal non-commercial research and education use, including for instruction at the authors institution and sharing with colleagues.

Other uses, including reproduction and distribution, or selling or licensing copies, or posting to personal, institutional or third party websites are prohibited.

In most cases authors are permitted to post their version of the article (e.g. in Word or Tex form) to their personal website or institutional repository. Authors requiring further information regarding Elsevier's archiving and manuscript policies are encouraged to visit:

http://www.elsevier.com/copyright 


\title{
Establishing the links between economic development and the restoration of natural capital
}

\author{
James Blignaut ${ }^{1}$, Karen J Esler ${ }^{2}$, Martin $\mathrm{P}$ de Wit $^{3}$, David Le Maitre ${ }^{4}$, \\ Suzanne $\mathrm{J} \mathrm{Milton}^{5}$ and James Aronson ${ }^{6,7}$
}

\begin{abstract}
We reviewed 1575 peer-reviewed papers on restoration published from January 2000 to September 2008 in 13 scientific journals to assess whether they considered the economic and policy implications of their research, and referred to the concept of, or emerging markets for, payments for ecosystem goods and services. Only 8\% (125 papers) of the 1575 papers reviewed referred to the establishment of markets and/or payment for ecosystem services or surrogates. The findings suggest that the linkages between natural capital and ecosystem services are not being made and thus the benefits of restoration are not being integrated into development planning. Better communication of the socio-economic and political benefits of restoration will be required if restoration is to be advanced.
\end{abstract}

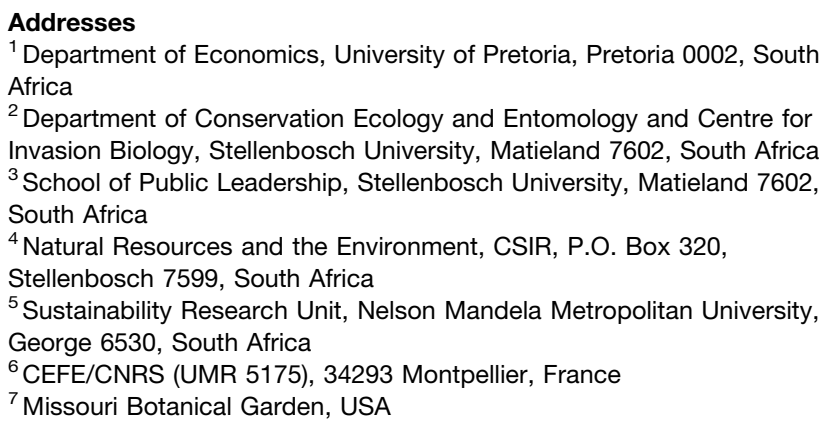

${ }^{1}$ Department of Economics, University of Pretoria, Pretoria 0002, South Africa

${ }^{2}$ Department of Conservation Ecology and Entomology and Centre for Invasion Biology, Stellenbosch University, Matieland 7602, South Africa ${ }^{3}$ School of Public Leadership, Stellenbosch University, Matieland 7602, South Africa

${ }^{4}$ Natural Resources and the Environment, CSIR, P.O. Box 320,

Stellenbosch 7599, South Africa

${ }^{5}$ Sustainability Research Unit, Nelson Mandela Metropolitan University, George 6530, South Africa

${ }^{6}$ CEFE/CNRS (UMR 5175), 34293 Montpellier, France

${ }^{7}$ Missouri Botanical Garden, USA

Corresponding author: Blignaut, James (jnblignaut@gmail.com)

Current Opinion in Environmental Sustainability 2013, 5:94-101
This review comes from a themed issue on Terrestrial systems
Edited by Bojie Fu, Martin Forsius and Jian Liu
For a complete overview see the Issue and the Editorial
Received 11 July 2012; Accepted 18 December 2012
Available online 8th January 2013
1877-3435/\$ - see front matter, C 2012 Elsevier B.V. All rights reserved.
http://dx.doi.org/10.1016/j.cosust.2012.12.003

\section{Introduction}

Renewable and cultivated natural capital provide the flow of ecosystem goods and services essential to human life [1]; intact or restored natural capital is, therefore, indispensable for economic development. Current approaches to development are unsustainable because people are depleting many of the finite stocks of natural capital at rates faster than they can regenerate [2]. For instance, according to some indicators and at the global scale, appropriation of fresh water and plant or animal biomass by humans far exceeds the rate at which these resources are replenished $[3,4]$.

Long-term sustainability requires society to invest in restoring natural capital to increase the supply of ecosystem goods and services [5] and to maintain biodiversity that is vital to ecosystem functionality. Rey Benayas $e t$ al. [6], Bullock et al. $\left[7^{\bullet \bullet}\right]$, and others have shown that restoration projects can enhance biodiversity and ecosystem goods and services simultaneously. But linkages between ecological restoration and economic development have only recently begun to be explored $\left[8,9^{\circ \bullet}\right]$. Although some studies have made this link [2,6,10-12], most of the scientific literature on ecological restoration rarely considers conceptual or methodological approaches for measuring its impacts on economic development. Clearly, the majority of restoration ecologists and socioeconomic scholars are still working in their own silos [13]. It is, therefore, no surprise that the drivers and symptoms of environmental degradation are seldom managed, or even perceived, in an integrated way when restoration projects and programmes are undertaken.

We screened papers published in 13 peer-reviewed academic journals for the period 2000-2008 to investigate whether restoration of natural capital is linked to the development of markets for ecosystem goods and services. We confined ourselves to the peer-reviewed scientific literature because it is available to search and review unlike the 'grey' (non peer-reviewed) literature. Academic research is not separate from, but rather an important step in, the successful development of evidencebased policy [14]. Some of the data used in this study were previously used to compare trends in ecological restoration research among journals $\left[15^{\bullet \bullet}\right]$ and to establish links between the academic disciplines of restoration and

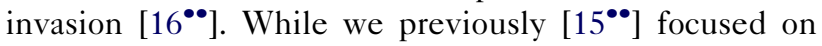
restoration science and its practitioners, this paper reviews the dataset from a socio-economic and policy perspective, broadening the focus. We therefore seek to answer the overarching question: 'Do the publications, that is, researchers and academic publishers, concerned with ecological restoration consider the economic and policy implications of their research, especially as represented by the market mechanism of payments for ecosystem goods and services (PES)?' We did not restrict the study to any particular PES definition (see Wunder [17] and Muradian et al. [18]), but rather accepted each set of authors' decisions as to whether their project 
constituted a PES project or not according to their own criteria and definitions.

\section{Method}

We followed a two-step process to narrow the focus of the study to key journals as described in Aronson et al. [15 $\left.{ }^{\bullet \bullet}\right]$. First, we searched a selection of papers for the words 'restoration' or 'rehabilitation' in the title, abstract or keywords. From this we narrowed the focus to 13 academic journals as listed in Annexure 1. The journal selection was also informed by the scope of papers published, their mission statements and target readership, as well as presumed relevance to the subject of this study. We considered these parameters to explicitly seek journals that would publish peer-reviewed papers on restoration, multi-disciplinary research related to restoration and/or PES. This sampling of journals is not exhaustive, but rather representative, in our view, of the relevant peer-reviewed literature of the stated period. The journals selected not only include a significant sampling of relevant ecological journals, but also two influential journals from the field of ecological and environmental economics.

Second, we screened all the papers (19547 in total) published in these 13 academic journals from 1 January 2000 to 1 October 2008, for the words 'restoration' and/or 'rehabilitation' in the title, abstract, or keywords. (Detailed methods are described in Aronson et al. $\left[15^{\bullet \bullet}\right]$.) All reference 'hits' were subsequently subjected

Table 1

List of variables and categories used for analysing the restoration papers to identify ('hits'). Many of the categories can have multiple answers for a given paper.

\begin{tabular}{|c|c|}
\hline Category & Keywords and definitions \\
\hline Paper descriptors & $\begin{array}{l}\text { Author, year of publication, title of the article, journal, location of the keyword identification (title, abstract, } \\
\text { and/or key words) }\end{array}$ \\
\hline $\begin{array}{l}\text { Ecosystem types in which the study } \\
\text { was conducted }\end{array}$ & $\begin{array}{l}\text { Grasslands, forests, woodlands, shrublands, savannas, arid (and semi-arid) regions, aquatic (rivers, other } \\
\text { wetlands, marine, and coastal), urban, human modified and transformed, other, or unclassified }\end{array}$ \\
\hline Restoration approach & $\begin{array}{l}\text { Active = implies that something was added or removed (e.g., re-seeding, fertilizer, irrigation, plants) } \\
\text { Passive = area was left to recover by itself } \\
\text { Not specified }\end{array}$ \\
\hline Restoration method used & Re-seeding, planting, succession, others, or not specified \\
\hline $\begin{array}{l}\text { Purpose of restoration; type of } \\
\text { ecosystem services affected } \\
\text { (as per MA [16] categories) }\end{array}$ & $\begin{array}{l}\text { Supporting = a service such as pollination or seed dispersal that makes it possible to produce crops } \\
\text { Regulating = a service that moderates environmental extremes or stabilises ecosystem components, } \\
\text { dynamics and functions - for example, control of floods, erosion, dust storms } \\
\text { Provisioning = direct values of goods that can be harvested, for example, firewood, craft materials, meat } \\
\text { Cultural = benefits that people get from visiting wild places - scenery, traditional rituals, relaxation, } \\
\text { scientific information }\end{array}$ \\
\hline $\begin{array}{l}\text { Constituents of well-being } \\
\text { addressed or affected }\end{array}$ & $\begin{array}{l}\text { Material = food, wood, fish, and other things, goods or products that people harvest from ecosystems } \\
\text { Health = health benefits of natural environments, for example, water purification, removal of toxins from the } \\
\text { air } \\
\text { Security = ways in which natural vegetation or functioning ecosystems protect our atmosphere or prevent or } \\
\text { minimise disasters such as floods or mudslides } \\
\text { Social relations = ways in which natural environments contribute to our cultural and social lives; care for the } \\
\text { innate value of biodiversity included here }\end{array}$ \\
\hline Well-being impact description & Description of how the restoration improves quality of life for people \\
\hline $\begin{array}{l}\text { Link to agricultural systems } \\
\text { or practices }\end{array}$ & $\begin{array}{l}\text { Does the restoration link with agricultural systems or practices? Yes/No. If Yes, in what way? For example, } \\
\text { crop production, forestry, ranching }\end{array}$ \\
\hline Monitoring tools used & $\begin{array}{l}\text { Yes/No. If Yes, description of how restoration was monitored. } \\
\text { Instrumental = measuring, for example, vegetation cover, species abundance, or soil parameters. } \\
\text { Interviews = asking people by phone or questionnaire about restoration project }\end{array}$ \\
\hline Scale of influence and interventions & $\begin{array}{l}\text { Level of ecological organisation, and specific kinds of interactions: } \\
\text { Landscape (spatial interactions) = covering many habitats or communities } \\
\text { Ecosystem (trophic interactions) = that the restoration influences plants, herbivores, and predators } \\
\text { Community (inter-specific interactions) = restoration affects many organisms } \\
\text { Population (re-introductions) = restoration focused on a single species }\end{array}$ \\
\hline $\begin{array}{l}\text { Policy outcome or (research) } \\
\text { recommendation }\end{array}$ & $\begin{array}{l}\text { This refers to the effect of the study of the restoration or the restoration itself on policy: none, locally (one town } \\
\text { or settlement), regionally, nationally (whole country), or global }\end{array}$ \\
\hline Policy intensity (scale of impact) & $\begin{array}{l}\text { The number of people directly or indirectly affected by the policy or the importance of the policy for the way in } \\
\text { which towns, nations, or the world is run: None, minor, major }\end{array}$ \\
\hline Host country & Country where restoration took place \\
\hline $\begin{array}{l}\text { PES (payment for } \\
\text { ecosystem services) }\end{array}$ & $\begin{array}{l}\text { Yes/No. This describes the ways in which restoring an environmental to provide better services can be } \\
\text { rewarded, for example, by tax credits or reductions. } \\
\text { If Yes, does the market actually exist or is it only perceived? } \\
\text { Formed = the reward method is functioning and that farmers, miners, NGO, and so on are actually receiving } \\
\text { some payment or other benefits for doing the restoration } \\
\text { Perceived = a possible method of reward has been described }\end{array}$ \\
\hline
\end{tabular}




\begin{tabular}{|c|c|c|c|c|}
\hline \multicolumn{5}{|c|}{ Number of papers scrutinised and the number dealing with either restoration or rehabilitation per year. } \\
\hline & $\begin{array}{c}\text { Total } \\
\text { scrutinised }\end{array}$ & $\begin{array}{l}\text { Total on restoration } \\
\text { or rehabilitation ('hits') }\end{array}$ & $\begin{array}{c}\% \text { of papers p.a. dealing } \\
\text { with restoration }\end{array}$ & $\begin{array}{c}\% \text { of restoration } \\
\text { papers }\end{array}$ \\
\hline 2000 & 1629 & 119 & $7.3 \%$ & $7.0 \%$ \\
\hline 2001 & 1686 & 109 & $6.5 \%$ & $6.9 \%$ \\
\hline 2002 & 1740 & 133 & $7.6 \%$ & $8.4 \%$ \\
\hline 2003 & 2098 & 154 & $7.3 \%$ & $9.8 \%$ \\
\hline 2004 & 2141 & 182 & $8.5 \%$ & $11.6 \%$ \\
\hline 2005 & 2391 & 228 & $9.5 \%$ & $14.5 \%$ \\
\hline 2006 & 2689 & 205 & $7.6 \%$ & $13.0 \%$ \\
\hline 2007 & 2506 & 236 & $9.4 \%$ & $15.2 \%$ \\
\hline $2008^{a}$ & 2667 & 216 & $8.1 \%$ & $13.6 \%$ \\
\hline Total & 19547 & 1582 & $8.1 \%$ & $100.0 \%$ \\
\hline
\end{tabular}

${ }^{a}$ Note that only the publications appearing in the first nine months of this year were included.

to content analysis [19], where the latent content or underlying meaning of the articles was coded by reading each article and assessing it against a predetermined list of variables and categories (presented in Table 1) selected to address our key question.

\section{Results}

Our search identified 19547 papers which were screened to gauge whether restoration was part of mainstream economic and ecological research and practice, leaving only 1582 'hits' $\left(8.1 \%\right.$ of all papers) [15 ${ }^{\circ \bullet}$ ] (Table 2). There was a moderate increase in the percentage of papers per annum dealing with restoration, from $6.8 \%$ in 2000 to $9.5 \%$ in 2007.

\section{Does ecological restoration research focus on particular ecosystem types?}

From the sample of studies reviewed it is clear that productive terrestrial ecosystems (forests, woodlands, savannas ecosystems, rivers and wetlands) were selected for restoration more frequently than marine or arid and semi-arid terrestrial ecosystems (Table 3). This could be due to under-representation in the sample, but more probably due to the fact that the relative ease of restoration, and the speed of achieving restoration success vary substantially across ecosystems and the location of most of these studies in Europe and the USA with extensive natural forests $\left[12,15^{\bullet \bullet}\right]$. Some journals were understandably focused on their area of specialisation. For example, Forest Ecology and Management provided 258 (17\%) of the total hits and $70 \%$ of these 258 hits dealt with forests, woodlands or shrublands. For Restoration Ecology, with 514 hits (33\% of the total), the corresponding value was $30 \%$. It should be noted that Restoration Ecology is a specialised subject-specific journal and hence it goes without saying that it should carry the most 'hits'. The economic and policy implication of this ecosystem bias is that there is a relatively poor understanding of the potential risks and costs associated with other ecosystems which makes payments for ecosystem services less attractive to private sector investors. However, there may well be sound reasons for restoration from a societal perspective in which case private-public partnerships or fully publicly funded interventions will still realise net benefits.

\section{To what extent are payments for ecosystem services reflected in this body of literature?}

Restoration research sought to improve the cultural $(28.5 \%)$, provisioning $(26 \%)$, regulating $(29 \%)$ or supporting $(16.5 \%)$ services provided by natural and seminatural

\section{Table 3}

Breakdown of all restoration or rehabilitation papers by ecosystem type. Percentage of papers is shown in parentheses. Bold entries indicate $>20 \%$ of the total restoration-related papers for that year. The grand total exceeds the 1582 papers examined since some of the studies covered more than one ecosystem type (not all percentages add up to 100 because of rounding).

\begin{tabular}{|c|c|c|c|c|c|c|c|c|c|}
\hline & Grasslands & $\begin{array}{l}\text { Forests, woodlands } \\
\text { and savannas }\end{array}$ & Shrublands & $\begin{array}{l}\text { Arid and semi-arid } \\
\text { ecosystems }\end{array}$ & $\begin{array}{l}\text { Rivers and } \\
\text { wetlands }\end{array}$ & $\begin{array}{c}\text { Marine and } \\
\text { coastal areas }\end{array}$ & $\begin{array}{l}\text { Urban and } \\
\text { transformed }\end{array}$ & Unclassified & Total \\
\hline 2000 & $11(7)$ & $40(26)$ & $2(1)$ & $5(3)$ & 59 (39) & $10(7)$ & $20(13)$ & $5(3)$ & $152(100)$ \\
\hline 2001 & $9(7)$ & 31 (24) & $6(5)$ & $1(1)$ & 40 (31) & $5(4)$ & 29 (22) & $10(8)$ & $131(100)$ \\
\hline 2002 & 20 (11) & $42(23)$ & $9(5)$ & $6(3)$ & $65(35)$ & 18 (10) & $23(12)$ & $3(2)$ & 186 (100) \\
\hline 2003 & 32 (17) & $39(21)$ & $16(8)$ & $6(3)$ & $39(21)$ & 22 (12) & $21(11)$ & $14(7)$ & 189 (100) \\
\hline 2004 & 25 (12) & 77 (36) & $5(2)$ & $8(4)$ & 40 (19) & $10(5)$ & $33(15)$ & $15(7)$ & $213(100)$ \\
\hline 2005 & 34 (13) & $76(28)$ & $8(3)$ & $4(1)$ & 87 (32) & $24(9)$ & $21(8)$ & $16(6)$ & $270(100)$ \\
\hline 2006 & 27 (12) & 71 (31) & $6(3)$ & $10(4)$ & $48(21)$ & $12(5)$ & 34 (15) & $19(8)$ & $227(100)$ \\
\hline 2007 & $33(11)$ & $82(28)$ & $8(3)$ & $13(4)$ & 74 (25) & $11(4)$ & 40 (14) & 32 (11) & $293(100)$ \\
\hline 2008 & 25 (10) & 79 (31) & $11(4)$ & $10(4)$ & $61(24)$ & $14(6)$ & $30(12)$ & 21 (8) & 251 (100) \\
\hline Total & 216 (11) & 537 (28) & $71(4)$ & $63(3)$ & $513(27)$ & $126(7)$ & 251 (13) & $135(7)$ & 1912 (100) \\
\hline
\end{tabular}


ecosystems (definitions of groups of services are based on the Millennium Ecosystem Assessment [20]. We classified activities which restore biodiversity or plant or animal populations as restoring cultural services, because threatened, endangered or otherwise 'special' species are valued as part of human natural heritage. There was little evidence that such restoration research was linked to material, supporting or regulating services. The human well-being objective of most restoration services was improved social relations, by increasing the supply of scarce services for example $(30 \%)$, and security by ensuring more reliable delivery of services that meet basic human needs (30\%). Fewer studies envisaged restoration outcomes that resulted in better health $(15 \%)$ or a greater supply of goods $(25 \%)$, the results being significant at a $10 \%$ level (Chi square $=13.3, P<0.1$ ). The implications for policy and economics of these knowledge gaps are that further research is needed to assess and quantify the likely or known changes ecosystem service generation and delivery and to assess and quantify the benefits and the potential for positive returns on PES.

\section{How is the link between ecological restoration and PES related to the level of economic development and wealth in specific countries?}

Most restoration papers $(72 \%)$ reported on research in high-income countries (Figure 1). Only 3\% were located in low-income countries, with India and eastern Africa (Ethiopia, Kenya, Tanzania and Uganda) contributing about $80 \%$ of these. Provisioning services were addressed significantly more often (Chi square $=23.2, P<0.01)$ in low-income countries $(41.5 \%)$ than high-income countries $(25 \%)$. The converse was true for research dealing with restoration to provide cultural services

Figure 1

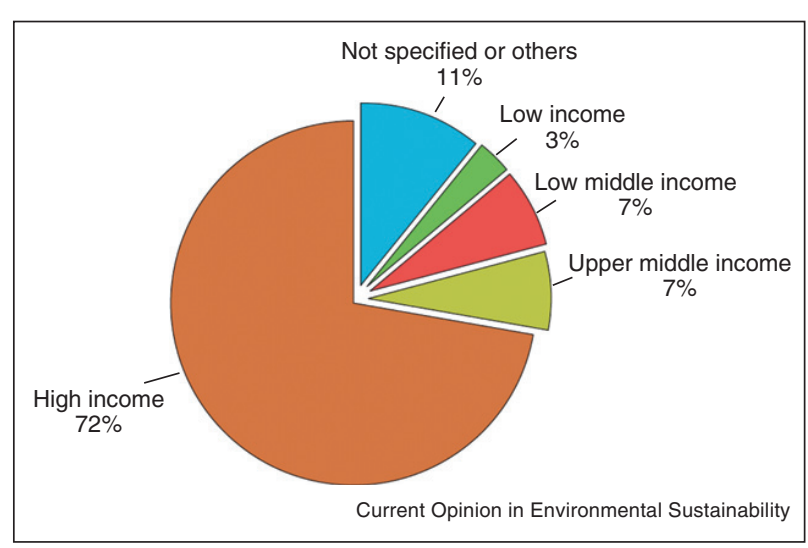

Distribution of studies by the economic status of the host country $(N=1582)$. Note: Economic development status follows the criteria of the World Bank (2007). Low-income countries have a gross national income per capita $(\mathrm{GNI} / \mathrm{c}$ ) of less than $\$ 875$. Low middle-income countries have a $\mathrm{GNI} / \mathrm{c}$ between $\$ 875$ and $\$ 3466$. Upper middle-income countries have a $\mathrm{GNI} / \mathrm{c}$ between $\$ 3466$ and $\$ 10725$. High-income countries have a $\mathrm{GNI} / \mathrm{c}$ of $\$ 10725$ or more.
Figure 2

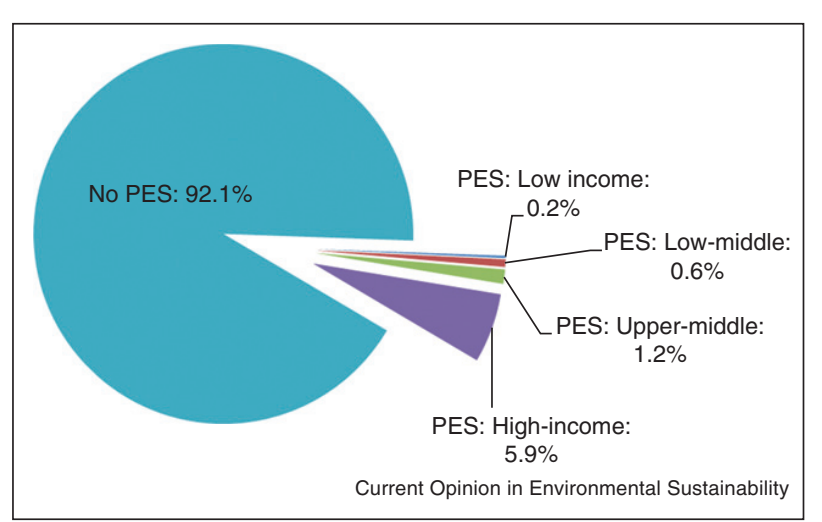

Proportional distribution of 1575 academic papers published in 13 journals over the period January 2000-September 2008 with respect to whether reference is made to payments for ecosystem goods and services (PES) (or markets or any surrogate economic institution and/or system) in terms of country-level development status.

(19\% for low-income countries compared to $29 \%$ for high-income). Only $37 \%$ of the papers from high-income countries reported on restoration of agricultural productivity compared with $53 \%$ of upper middle-income, $43 \%$ for low middle-income and $56 \%$ of low-income countries; the differences were statistically significant (Chi square $=16.06, P<0.01$ ). Restoration was linked to payments for ecosystem goods and services in $12 \%$ of upper middle-income country studies (mainly Mexico, Costa Rica, Poland, South Africa and the Czech Republic), but in only $7 \%$ of studies from high-income countries. In total, however, only $8 \%$ of the papers (125 papers in total) referred to the establishment of markets and/or payment for ecosystem services systems or any surrogate for them (see Figure 2). These findings have important implications for developing countries where the benefits of PES are often promoted as a way of addressing the ongoing degradation of natural resources they experience. Although much of the research from developed countries may be useable, there will be many knowledge gaps as the dominant ecosystems differ from each other, (e.g., tropical forests, semi-arid and arid savannas and shrublands) and the understanding of how to implement PES within the political, governance and societal structures in these countries is not only weak, but also the skills base in actually undertaking the restoration is weak.

\section{If there is a link between ecological restoration and its policy implications in academic literature, what is its impact?}

Between $70 \%$ and $80 \%$ of the papers indicated no or only local policy outcomes (please note Table 1 for a definition) (Figure 3(a)), although the frequency of policy links increased slightly since 2006. The frequency of policy links does not change with national income 
Figure 3

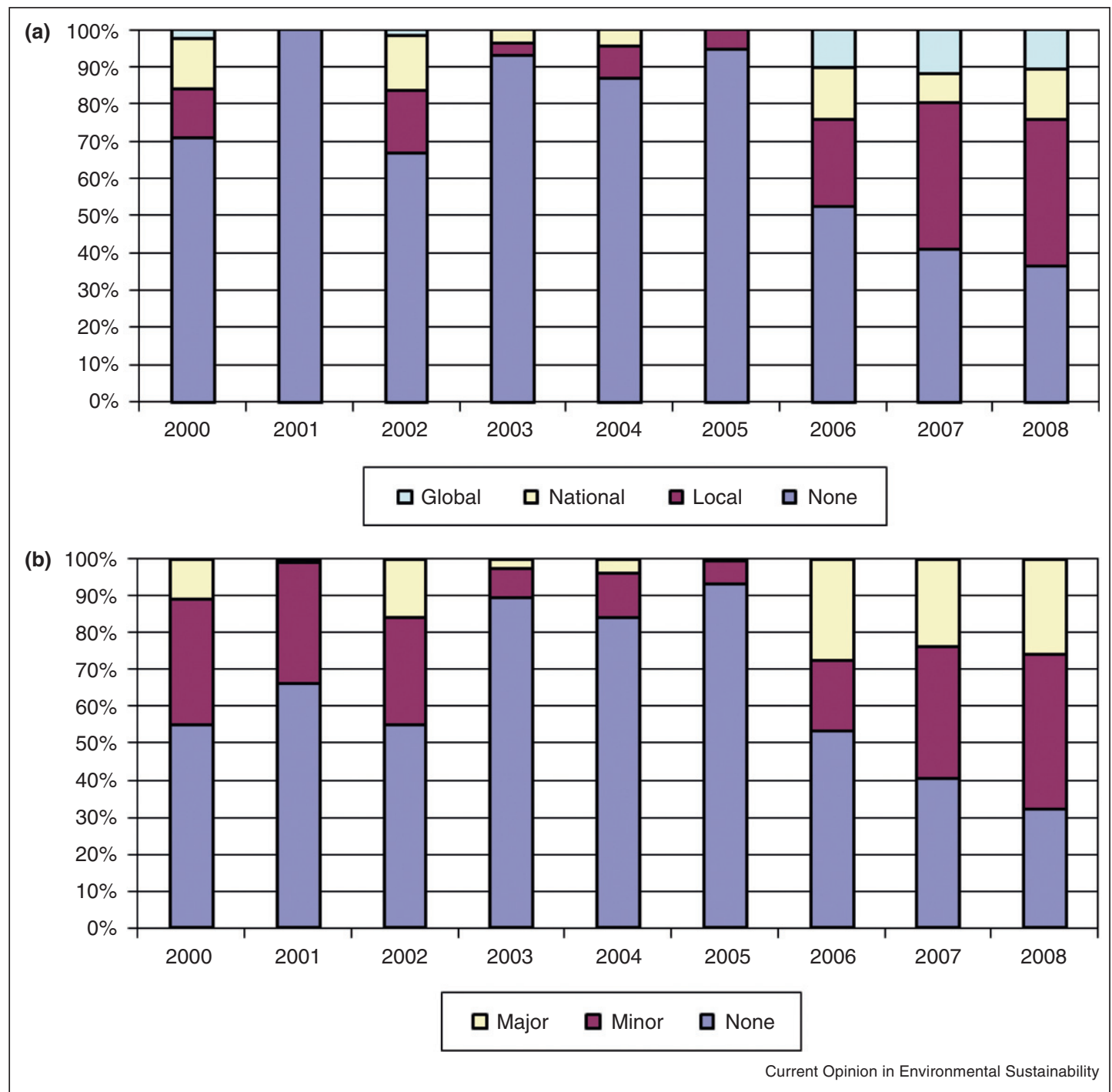

(a) The indicated policy outcome of restoration-related studies. (b) The intensity of restoration-related studies (in both cases: $N(2000)=113$; $N(2001)=109 ; N(2002)=133 ; N(2003)=154 ; N(2004)=182 ; N(2005)=228 ; N(2006)=203 ; N(2007)=240 ; N(2008)=223 ; N($ total $)=1585)$

(Chi square $=0.03, P=0.94)$. Similarly, policy intensity rating (Figure 3(b)), a measure of the socio-economic impact of policy implementation, was generally low, with more than $70 \%$ of the papers either having no or only a minor impact. As noted in the previous section, understanding of the policy outcomes of PES and other restoration funding options, such as the full benefits to society, will make it much harder to convince governments and other bodies to explore such options. This is particularly so when there are other options for pursuing development, many of which have much better returns in the short-term but are not sustainable and may result in significant environmental and socio-economic costs in the future.

\section{Discussion}

Academic ecologists working at the level of ecosystems have focused primarily on the functioning and evolutionary dynamics of ecological systems in near natural states, rather than on modified and transformed systems inhabited and dominated by people. Although restoring ecosystems may provide a significant test of ecological models and theory [21], academics tend to favour fundamental science, as this is generally rated more highly than applied science in academic institutions and by most funding agencies [22-24]. However, we found that the number of papers dealing with ecological restoration is increasing, confirming the trend over the last 40 years reported by Ormerod [25]. Although this shift is 
encouraging it is not strongly linked to showing how such restoration may benefit society through changes in the generation and delivery of ecosystem services.

The evidence provided seems to indicate a strong 'biome bias' towards restoration in rivers and wetlands, probably because of the rapidly increasing need for clean water, and towards productive terrestrial systems such as forests, woodlands and moist savannas [26]. Less productive and more remote systems (e.g., deep sea, arid savannas, true desert) received less attention, supporting the findings of Lawler et al. [27] in their review of 628 conservation research papers. The emphasis on livelihood-linked provisioning services in the papers studied decreases from poor to rich host countries, and conversely, the importance of a social and cultural focus increases. This may imply that research in the more affluent countries on ecological restoration emphasises biodiversity or intact ecosystems for their existence value, rather than placing them in the context of their value for society, a distinction rarely made explicit (see also Daily [28] and Sandler [29] for further reading on this topic). In high-income countries, the focus of restoration research on cultural services suggests that biodiversity issues, or recreational, aesthetic and amenity values of environments are the major drivers of restoration. The semi-arid and arid areas of the world, where a large proportion of the world's poorest live, are probably to the most adversely affected by global change. So the lack of research into restoration in semi-arid and arid ecosystems, linked with the lack of research into full benefits to society, will make it hard to promote PES in the areas where restoration is probably to be needed the most.

The weak link between research on ecological restoration and payments for ecosystem services, even in the upper middle-income countries that lead the field internationally, is noteworthy. Only $8.1 \%$ (or 125 papers) of the 1582 restoration papers reviewed (i.e., $0.6 \%$ of all the papers (19 547) scrutinised) referred to the establishment of markets or systems for valuation and payment for ecosystem services improved by restoration. Restoration, however, is not location neutral as we found that restoration studies in poorer countries emphasised adding value to agricultural systems (e.g., maintaining productivity of cultivated lands); a finding corroborated by Rey Benayas et al. [30]. Although this does reflect a focus on key services for food security, the number of studies is very limited so the knowledge base is very weak, especially for local varieties of internationally grown crops as well as local crop species.

Public policy on conservation and restoration is increasing in importance due to acute and ongoing degradation. Our findings, however, suggest that most restoration research is focused on biodiversity maintenance and testing of new approaches, methods or applications (i.e., best-practice), rather than influencing policy; less than $30 \%$ of papers addressed direct policy impacts. This is indicative of a disconnect between restoration research, socio-economic value and policy issues and this will have to be addressed so that decision makers can appreciate that although the initial costs may be high, the medium and long-term benefits will be significant.

This study may be biased by limiting searches to English language academic journals. Future research should include journals in other languages, grey literature and interviews with restoration managers and financiers to explore perceptions of the changing value of restoration.

Policy-makers and managers in all countries should consider developing markets and payments for improved ecosystem services following restoration. Markets are social constructs based on popular demand. Active pursuit of markets integrated with the restoration of natural capital, would show that benefits resulting from ecological restoration justify investment. Conversely, the absence of markets for restoring natural capital would indicate either that there is insufficient value, or that scientists, policymakers and society in general fail to recognise the value of restoration for human well-being. A lack of markets, or debate about market potential, at least in market-orientated countries, could suggest failure to communicate the benefits of restoration, failure to involve social institutions in restoration initiatives, or an acceptance of the ideology that restoration is not marketable [13].

\section{Conclusion}

Our review provides strong evidence that academic restoration ecologists do not adequately recognise the tangible contributions of restoration to society, and that the concept of ecosystem services (i.e., explicitly linking services to beneficiaries and demonstrating values) has not yet been mainstreamed in the science, public policy or practice of ecological restoration. It is also probably that academic resistance to truly cross-disciplinary studies inhibits collaboration between researchers of ecosystem services and ecological restoration. A new research initiative within the International Council for Science global change programmes, the Programme on Ecosystem Change and Society [31], provides a perfect transdisciplinary platform within which such scientific and policyrelevant knowledge of social-ecological systems can be generated. Restoration can significantly increase natural capital and thus the flow of services and benefits to society; but restoration ecologists need to make these links explicit and provide evidence to convince society that the benefits outweigh the investment costs.

\section{Acknowledgements}

The Water Research Commission which, through contract K5/1803 'The impact of re-establishing indigenous plants and restoring the natural landscape on sustainable rural employment and land productivity through payment for ecosystem services' together with ASSET Research made this study possible. We also thank Christelle Fontaine, Ned Lederer, Philip Prinsloo, Leandri van der Elst, Worship Mugido and Amandine Limouzin for valuable comments on the manuscript and for help in developing the database. 


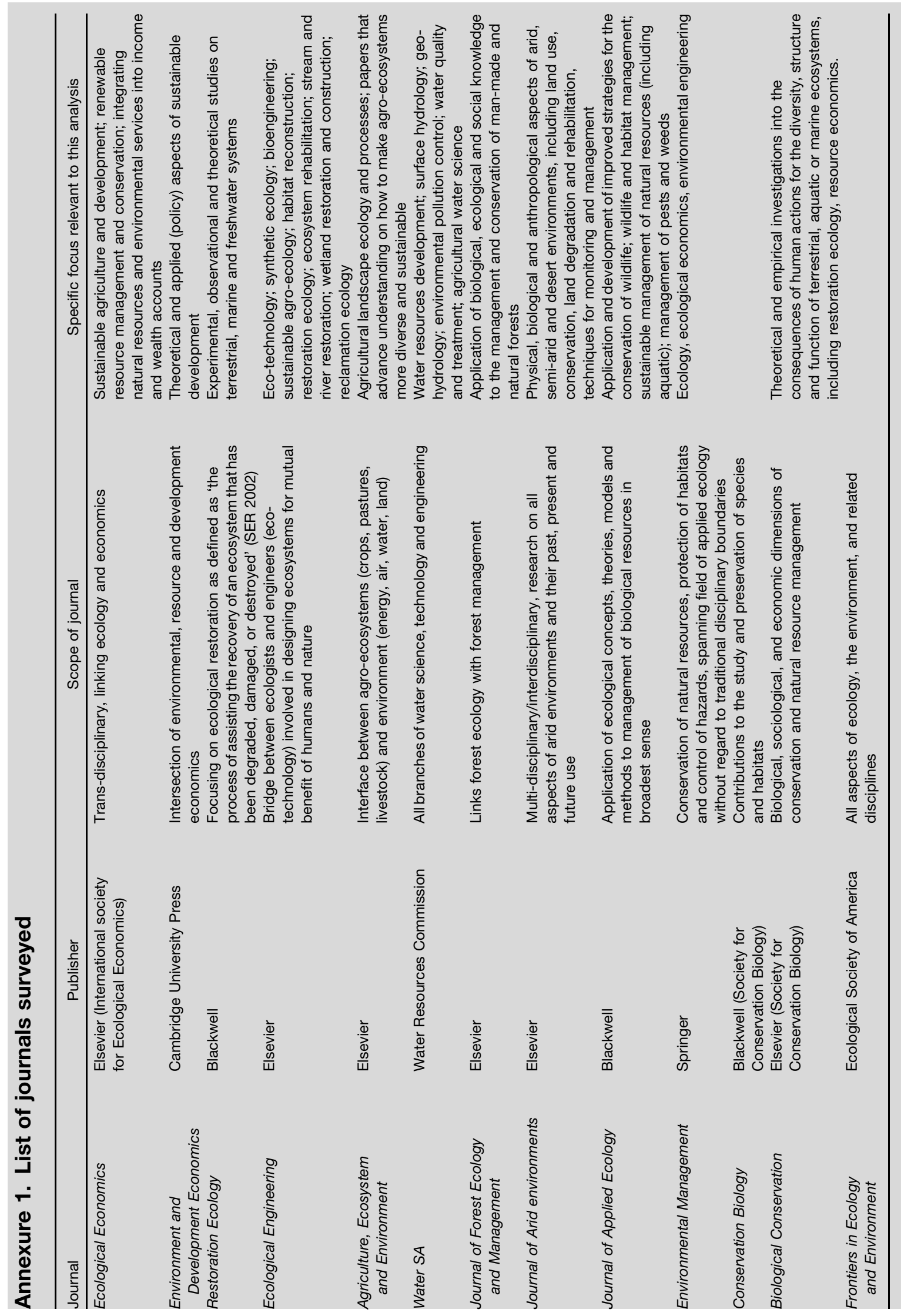




\section{References and recommended reading}

Papers of particular interest, published within the period of review, have been highlighted as:

- of special interest

$\bullet$ of outstanding interest

1. Nelson E, Mendoza G, Regetz J, Polasky S, Tallis H, Camero DR, Chan KMA, Daily GC, Goldstein J, Kareiva PM et al.: Modeling multiple ecosystem services, biodiversity conservation, commodity production, and tradeoffs at landscape scales.

Front Ecol Environ 2009, 7:4-11.

2. WWF: Living planet report. WWF and Global Footprint Network; 2010.

3. Duraiappahn AK: Poverty and environmental degradation: a review and analysis of the nexus. World Dev 1998 , 26:2169-2179.

4. Vitousek PM, Mooney HA, Lubchenco J, Melillo J: Human domination of earth's ecosystems. Science 1997, 277:494-499.

5. Blignaut JN, Aronson J: Getting serious about maintaining biodiversity. Conserv Lett 2008, 1:12-17.

6. Rey Benayas JM, Newton AC, Diaz A, Bullock JM: Enhancement of biodiversity and ecosystem services by ecological restoration: a meta-analysis. Science 2009, 325:1121-1124.

7. Bullock J, Aronson J, Rey Benayas JM, Pywell R, Newton A:

-. Restoration of ecosystem services and biodiversity. Trends Ecol Environ 2011 http://dx.doi.org/10.1016/j.tree.2011.06.011.

This paper explores the link between restoration and biodiversity and the need to push the notion of restoration more towards the forefront within the biodiversity conservation agenda

8. Neßhöver C, Aronson J, Blignaut JN, Lehr D, Vakrou A, Wittmer H: Investing in ecological infrastructure. In The Economics of Ecosystems and Biodiversity in National and International Policy Making: Addressing the Challenges for Policy Makers. Edited by ten Brink P. London: Earthscan; 2011:401-448.

9. Yin R, Zhao M: Ecological restoration programs and payments

-. for ecosystem services as integrated biophysical and socioeconomic processes-China's experience as an example. Ecol Econ 2012, 73:56-65.

This paper provides a very good example of the need for integration among disciplines when conducting restoration, also from a developing economy perspective

10. Young TP: Restoration ecology and conservation biology. Biol Conserv 2000, 92:73-83.

11. Aronson J, Milton S, Blignaut JN: Conceiving the science, business and practice of restoring natural capital. Ecol Restor 2006, 24:22-24.

12. Aronson J, Milton SJ, Blignaut (Eds): Restoring Natural Capital: Science, Business and Practice. Island Press; 2007.

13. Aronson J, Blignaut JN, de Groot R, Lowry PP II, Clewell A, Woodworth P, Cowling RM, Renison D, Levy-Tacher S, Tongway D et al: : The road to sustainability must bridge three great divides. Ann N Y Acad Sci 2010, 1185:225-236.

14. Strydom WF, Funke N, Nienaber S, Nortje K, Steyn M: Evidencebased policymaking: a review. South African J Sci 2010, 106:1-8.

15. Aronson J, Blignaut JN, Milton SJ, le Maitre D, Esler KJ,

-. Limouzin A, Fontaine C, de Wit M, Mugido W, Prinsloo P et al.: Are socio-economic benefits of restoration adequately quantified? A meta-analysis of recent papers (2000-2008) in Restoration Ecology and 12 other scientific journals. Restor Ecol 2010, 18:143-154.

This paper contains an analysis of a selection of the socio-economic impacts of restoration focussing on restoration practitioners

16. Gaertner M, Fisher JL, Sharma GP, Esler KJ: Insights into

-. invasion and restoration ecology: time to collaborate towards an holistic approach to tackle biological invasions. Neobiota 2012, 12:57-76.

This papers applies the need for multi-disciplinary approaches towards restoration within a specific form of restoration, namely the clearing of invasive alien plant species

17. Wunder S: Payments for Environmental Services: Some Nuts and Bolts. Occasional Paper No. 42. Nairobi, Kenya, Center for International Forestry Research; 2005.

18. Muradian R, Corbera E, Pascual U, Kosoy N, May PH: Reconciling theory and practice: an alternative conceptual framework for understanding payments for environmental services. Ecol Econ 2010, 69(6):1202-1208.

19. Babbie E, Mouton J: The Practice of Social Research. Oxford University Press; 2001.

20. MEA (Millennium Ecosystem Assessment): Ecosystems and Human Wellbeing: Multiscale Assessments. In Synthesis Report Series. Washington, DC: Island Press; 2005.

21. Harper JL: The heuristic value of ecological restoration. In Restoration Ecology: a Synthetic Approach to Ecological Research. Edited by Jordan III WR, Gilpin ME, Aber JD. Cambridge University Press; 1987:35-46.

22. Briggs SV: Integrating policy and science in natural resources: why so difficult? Ecol Manage Restor 2006, 7:37-39.

23. Esler KJ, Prozesky HE, Sharma G, McGeoch M: How wide is the 'knowing-doing' gap in Invasion Biology? Biol Invas 2010, 12:4065-4075.

24. Cambell LM: Overcoming obstacles to interdisciplinary research. Conserv Biol 2005, 19(2):574-577.

25. Ormerod SJ: Restoration in applied ecology: Editor's introduction. J Appl Ecol 2003, 40:44-50.

26. Buijs AE: Public support for river restoration. A mixed-method study into local residents' support for and framing of river management and ecological restoration in the Dutch floodplains. J Environ Manage 2009, 90:2680-2689.

27. Lawler JJ, Aukema J, Grant J, Halpern B, Kareiva P, Nelson CR, Ohleth K, Olden JD, Schlaepfer MA, Silliman B et al.: Conservation science: a 20-year report card. Front Ecol Environ 2006, 4:473-480.

28. Daily (Ed): Nature's Services: Societal Dependence on Natural Ecosystems. Island Press; 1997.

29. Sandler R: Intrinsic value, ecology, and conservation. Nat Educ Knowl 2012, 3(3):4

30. Rey Benayas JM, Bullock JM, Newton AC: Creating woodland islets to reconcile ecological restoration, conservation, and agricultural land use. Front Ecol Environ 2008, 6:329-336.

31. Carpenter SR, Folke C, Norström A, Olsson O, Schultz L, Agarwal B, Balvanera P, Campbell B, Castilla JC, Cramer W et al.: Program on ecosystem change and society: an international research strategy for integrated social-ecological systems. Curr Opin Environ Sustain 2012, 4:1-5. 